\title{
Pengaruh Kepadatan Kerang Kijing Taiwan (Anadonta woodiana, Matens 1874) Sebagai Biofilter Terhadap Parameter Fisik Media Pemeliharaan Ikan Nila
}

\author{
[Effects Of Taiwan freshwater Mussels (Anadonta Woodiana, Martens 1874) Density as a \\ Biofilter on Water Physical Parameters in Rearing of Tilapia]
}

\author{
Rosmida Kasmin ${ }^{1}$, Abdul Rahman ${ }^{1 *}$, Ruslaini ${ }^{1}$ \\ ${ }^{1}$ Program Studi Budidaya Perairan, Fakultas Perikanan dan Ilmu Kelautan, Universitas Halu Oleo \\ Jl. HEA Mokodompit Kampus Bumi Tridharma Anduonohu, Kendari 93232 Indonesia \\ *Email korespondensi : abdulrahman@uho.ac.id
}

\begin{abstract}
ABSTRAK
Penelitian ini bertujuan untuk mengetahui pengaruh kepadatan kerang Kijing Taiwan (A.woodiana) sebagai biofilter terhadap parameter fisik media pemeliharaan ikan nila (Oreochromis niloticus). Sebanyak 15 ekor ikan nila dipelihara bersama kijing Taiwan dengan kepadatan berbeda sesuai perlakuan penelitian yaitu kontrol (perlakuan A), 3 ind/wadah (perlakuan B), 4 ind/wadah (perlakuan C), dan 5 ind/wadah (perlakuan D). Ikan nila dipelihara selama 30 hari dan diberi pakan pellet secara adlibitum pada pagi dan sore hari. Hasil penelitian diperoleh nilai variabel Total Suspended Solid (TSS) untuk masing-masing perlakuan tersebut secara berurut yaitu $0,90 \mathrm{mg} / 1,0,88 \mathrm{mg} / 1,0,58 \mathrm{mg} / 1$, dan $0,45 \mathrm{mg} / \mathrm{l}$. Nilai variabel Total Organic Matter (TOM) juga secara berurut adalah 4,31 mg/l, 2,25 mg/l, 1,88 mg/l, dan 1,82 mg/l. Variabel pertumbuhan mutlak organisme ikan nila pada masing-masing perlakuan yang juga secara berurutan adalah 18,53 $\pm 1,07 \mathrm{~g}$, $19,72 \pm 0,38 \mathrm{~g}, 20,62 \pm 0,90 \mathrm{~g}$, dan 21,45 $\pm 1,65 \mathrm{~g}$ dengan tingkat kelangsungan hidup $100 \%$ untuk semua perlakuan. Hasil Anova diperoleh petunjuk bahwa terhadap variabel TSS tidak berpengaruh nyata antar perlakuan, namun terhadap variabel TOM dan pertumbuhan mutlak memberikan pengaruh secara signifikan, sedangkan kelangsungan hidup tidak berpengaruh antar semua perlakuan. Secara umum, hadirnya organisme kijing taiwan dengan kepadatan yang cukup sebagai biofilter dapat menekan laju peningkatan parameter fisik media (TSS dan TOM) dan sangat mendukung kehidupan ikan nila $(O$. niloticus) selama proses pemeliharaannya berlangsung.
\end{abstract}

Kata Kunci ; Anadonta woodiana, ikan nila, TSS, TOM, pertumbuhan.

\section{ABSTRACT}

This study aimed to evaluate the effect of density of Taiwan freshwater mussels (Anadonta woodiana) as a biofilter on water physical parameters during rearing of tilapia (Oreochromis niloticus). A total of 15 tilapia were reared with Taiwan mussels with different densities according to the research treatment, namely control, 3, 4, and $5 \mathrm{ind} /$ container. Tilapia were reared for 30 days and fed pellets ad libitum in the morning and evening. The results obtained that the variable value of Total Suspended Solid (TSS) was $0.90 \mathrm{mg} / 1,0.88 \mathrm{mg} / 1,0.58 \mathrm{mg} / 1$, and $0.45 \mathrm{mg} / 1$, respectively. The value of the Total Organic Matter (TOM) was $4.31 \mathrm{mg} / 1,2.25 \mathrm{mg} / 1,1.88 \mathrm{mg} / 1$, and $1.82 \mathrm{mg} / \mathrm{l}$, respectively. The absolute growth variables of tilapia organisms in each treatment which were also sequentially were $18.53 \pm 1.07 \mathrm{~g}, 19.72 \pm 0.38 \mathrm{~g}, 20.62 \pm 0.90 \mathrm{~g}$, and $21.45 \pm 1.65 \mathrm{~g}$ with $100 \%$ survival rate for all treatments. The results of the ANOVA indicated that the TSS variable had no significant effect between treatments, but the TOM and absolute growth variables had a significant effect, while survival had no effect between all treatments. In general, the presence of Taiwan mussel organisms with sufficient density as a biofilter can reduce the rate of increase in the physical parameters of the media (TSS and TOM) and greatly support the life of tilapia $(O$. niloticus) during rearing period.

Keywords: Anadonta woodiana, tilapia, TSS, TOM, growth.

\section{PENDAHULUAN}

Ikan nila memiliki prospek dalam pengembangan budidaya karena peningkatan konsumsi ikan per kapita per tahun penduduk dunia yang meningkat tajam seiring dengan peningkatan laju pertumbuhan penduduk. Ikan nila juga banyak disukai masyarakat karena mempunyai rasa daging yang enak dan mempunyai kandungan protein $17,5 \%$. Menurut Food and Agriculture Organisation (FAO) budidaya ikan diperkirakan akan meningkat sekitar 172 ton pada tahun 2021, jumlahnya naik $15 \%$ dari rata-rata kebutuhan tahun 20092011. Peluang usaha yang masih terbuka luas untuk dikembangkan menyebabkan pembudidaya berupaya dalam meningkatkan nilai produksi spesies tersebut setiap tahun. Cara yang sering dilakukan para pembudidaya untuk meningkatkan produksi ikan nila adalah dengan menerapkan sistem intensif dengan padat tebar yang tinggi (Vrahmana, $d k k$. 2013).

Ciri dari tingginya peningkatan produksi budidaya intensif yaitu meningkatnya padat tebar yang diikuti dengan peningkatan jumlah 
pakan yang menimbulkan peningkatan limbah budidaya (Avnimelech, 2005). Ikan memakan sebagian besar pakan yang diberikan tetapi presentase terbesar diekskresikan menjadi buangan metabolisme. Sisa budidaya ikan mengeluarkan bahan organik berasal dari sisa pakan dan metabolisme yang banyak mengandung bahan organik yang tinggi. Ikan mengeluarkan $80 \%-90 \%$ bahan organik melalui proses osmoregulasi, feses dan urine. Buangan bahan organik dari sisa budidaya ikan ke perairan umum menyebabkan terjadinya penurunan kualitas air, terganggunya keseimbangan ekosistem, daya guna air yang terbatas hingga masalah kesehatanmasyarakat. Sehingga perlu pengelolaan terlebih dahulu bahan organik sebelummelepaskan di perairan umum. Usaha yang dapat dilakukan untuk mengatasi sisaaktivitas budidaya ikan dengan cara biofilter air (Tullah, 2018).

Biofilter berfungsi mengurangi bahan organik terlarut melalui penyerapan. ilter yang digunakan dalam penelitian ini yaitu biofilter kijing air tawar karena mampu menjernihkan air berkat efisiensinya menyaring partikel-partikel tersuspensi dan alga. Kijing termasuk hewan filter feeder dan mampu menyaring partikel berukuran antara $0.1-50.0 \mu \mathrm{m}$ dari badan air, selanjutnya pada ukuran partikel $>4.0 \mu \mathrm{m}$ mampu memfiltrasi hingga mencapai $100 \%$ (Putra, dkk. 2016).

Kijing Taiwan, merupakan salah satu jenisbivalvia air tawar yang berasal dari Taiwan, A. woodiana merupakan hewan filter feeder non selective dan sessil (menetap) yang mampu menyaring partikellebih besar dari 4 mikron. Secara biologis kijing taiwan dapat hidup di beberapaekosistem perairan tawar, memiliki kemampuan menyedot air dan memfilter partikel dalam air 40 1/hari/ind dan dapat mengekstrak bahan-bahan bersifat koloid, kandungan bahan organik baik tersuspensi maupun partikel, dengan kemampuan menurunkan kandungan bahan organik di perairan rata-rata mencapai 99,5\% (Karnaukhov 1997 dalam Putra dkk, 2016).

Berdasarkan penelitian Palinussa (2010) biofilter kijing taiwan dinilai cukup efektif dalam mereduksi padatan tersuspensi total (Total Suspended Solid) dimana padatan tersuspensi berkurang sebesar 99,5\% , sementara nilai kandungan oksigen terlarut (Dissolved Oxygen) berkisar 3,5-5,8 mg/1.
Untuk kadar amoniak kijing taiwan dapat mereduksi amoniak sehinnga amoniak total dalam perairan berkisar $0,02 \mathrm{mg} / 1$, sedangkan nilai $\mathrm{pH}$ yang dihasilkan biofilter ini berkisar $6,0-7,6$

Untuk perbaikan kualitas air dapat dilakukan dengan cara filterisasi baik secara mekanik, kimia dan biologi. Namun salah satu sistem filterisasi yang digunakan yang baik tanpa efek samping ialah filterisasi biologi atau dikenal biofilter. Biofilter yang digunakan dapat menggunakan bahan seperti kerang, rumput laut dan bakteri (Tullah, 2018)

Kegiatan pemeliharaan ikan nila $(O$. niloticus) dapat menghasilkan limbah organik yang cukup besar sehingga berdampak pada penurunan kualitas air dan penggunaan air yang cukup besar. Salah satu upaya untuk menurunkan bahan organik yang berasal dari sisa aktivitas budidaya ikan dan menekan penggunaan air yang besar dalam budidaya seperti budidaya Ikan Nila (O. niloticus) adalah dengan pemanfaatan organisme yang bersifat biofilter dan dapat dipelihara secara bersama dengan jenis ikan budidaya tersebut. Kijing taiwan (A. woodiana) adalah salah satu jenis organisme yang dapat berfungsi sebagai biofilter dan memiliki fungsi yang mampu memanfaatkan bahan-bahan organik sisa dalam media pemeliharaan organisme budidaya, hanya saja efektivitas dalam berperan menjaga kualitas media selama pemeliharaan ikan berlangsung terutama pada pemeliharaan ikan nila di akuarium belum tersedia informasi yang memadai, sehingga perlu dilakukan penelitian dengan tujuan untuk mengetahui pengaruh kepadatan $A$. woodiana sebagai biofilter terhadap parameter fisik media pemeliharaan ikan nila (Oreochromis niloticus).

\section{BAHAN DAN METODE}

Penelitian dilaksanakan pada bulan September-Oktober 2019, bertempat di ruang Laboratorium Unit Pembenihan dan Pembesaran Ikan FPIK-UHO. Analisis parameter fisik kualitas media budidaya (TSS dan TOM) di uji di Laboratorium Pengujian FPIK-UHO.

\section{Persiapan wadah dan hewan uji}

Wadah yang digunakan dalam penelitian ini adalah aquarium berukuran $35 \times 40 \times 35 \mathrm{~cm}^{3}$ sebanyak 12 buah. Semua wadah dilengkapi 
Media Akuatika : Jurnal Ilmiah Jurusan Budidaya Perairan. 2021. 6(4): 174-183.

dengan sistem aerasi dan diisi air tawar steril sebanyak 42 liter sebagai media pemeliharaan organisme budidaya dan organisme biofilter.

Kijing taiwan $(A$. woodiana) dengan berat rata-rata $11 \mathrm{~g} / \mathrm{ind}$, digunakan sebagai agen biofilter, diperoleh dari hasil tangkapan di alam. Kijing taiwan ditempatkan dalam setiap akuarium dengan kepadatan berdasarkan perlakuan penelitian. Hewan uji lainnya adalah ikan nila (O. niloticus) sebagai organisme budidaya target. Ikan nila ditebar sebanyak 15 ekor dengan berat rata-rata awal 6 g/ekor. Kedua jenis hewan uji tersebut, terlebih dahulu diadaptasikan pada lingkungan pemeliharaan selama satu minggu.

\section{Pemeliharaan Hewan Uji}

Ikan nila (O. niloticus) diberi pakan buatan berupa pellet dengan frekuensi pemberian dua kali sehari (pagi dan sore hari) secara adlibitum selama 30 hari pemeliharaan. Berbeda dengan kijing taiwan (A. woodiana) yang dalam budidaya ini tidak secara langsung diberi pakan. Kebutuhan pakan untuk kerang kijing taiwan diharapkan dapat memanfaatkan sisa-sisa pakan, feses dan hasil eksresi ikan nila yang dipelihara bersama dalam akuarium. Olehnya selama periode pemeliharaan hewan uji tidak dilakukan pergantian air dan sifon kotoran yang mengendap di dasar wadah.

\section{Rancangan Penelitian}

Penelitian ini menggunakan rancangan acak lengkap (RAL) yang terdiri dari 4 perlakuan dan 3 ulangan. Sebagai perlakuan adalah kepadatan kijing taiwan dalam wadah akuarium pemeliharaan ikan nila. Keempat perlakuan tersebut adalah tanpa kijing taiwan (Perlakuan A), kepadatan 3 individu kijing taiwan (Perlakuan B), kepadatan 4 individu kijing taiwan (Perlakuan C), dan kepadatan 5 individu kijing taiwan.

\section{Variabel Penelitian}

\section{Total Suspended Solid (TSS)}

Pengukuran TSS (Total Suspended Solid) dihitung dengan mengikuti rumus yang digunakan Fatimah et al. (2014) yaitu:

$$
\operatorname{TSS}(\mathrm{mg} / \mathrm{l})=\frac{(\mathrm{A}-\mathrm{B}) \times 1000}{\mathrm{~V}}
$$

Dengan: $\mathrm{TSS}=$ total suspended solid $(\mathrm{mg} / \mathrm{l}) ; \mathrm{A}=$ berat awal filter dan residu (mg); $\mathrm{B}=$ berat akhir filter dan residu (mg); $\mathrm{V}=$ Volume sampel dengan satuan $(\mathrm{ml})$

\section{Total organic matter (TOM)}

\section{Pengukuran TOM (Total Organic} Matter) dihitung dengan mengikuti rumus yang sama dengan Tullah (2018) yaitu :

$$
\mathrm{TOM}=\frac{(\mathrm{X}-\mathrm{Y}) \times 31,6 \times 0,01 \times 1000}{\text { vol air sampel }}
$$

Dengan: $\mathrm{TOM}=$ total organic matter $(\mathrm{mg} / \mathrm{l}) ; \mathrm{X}=$ larutan $\mathrm{KMNO}_{4}$ yang digunakan dalam titrasi (ml); $\mathrm{Y}=$ larutan aquades yang digunakan dalam titrasi (ml)

Untuk menghitung jumlah $\mathrm{KMNO}_{4}(\mathrm{X}$ dan Y) yang digunakan dalam titrasi larutan sampel, dilaksanakan sesuai petunjuk Indriyastuti, et.al. (2014).

\section{Pertumbuhan Mutlak}

Pertumbuhan Mutlak ikan nila dihitung dengan menggunakan petunjuk Safaringga et.al. (2017) yaitu :

\section{$\mathrm{PM}=\mathrm{Wt}-\mathrm{Wo}_{0}$}

Dengan: $\mathrm{PM}=$ Pertumbuhan Mutlak (g); $\mathrm{Wt}=$ Bobot akhir penelitian (g); $\mathrm{W} 0=$ Bobot awal penelitian (g).

\section{Tingkat Kelangsungan Hidup}

Tingkat kelangsungan hidup ikan nila dihitung dengan menggunakan petunjuk Sari et.al. (2017), yaitu :

$$
\mathrm{SR}=\frac{\mathrm{Nt}}{\mathrm{No}} \times 100 \%
$$

Dengan: $\quad \mathrm{SR}=$ Tingkat kelangsungan hidup (\%); $\mathrm{Nt}=$ Jumlah ikan pada akhir pemeliharaan; No=Jumlah ikan pada awal pemeliharaan.

\section{Analisis Data}

Data-data yang di peroleh dianalisa menggunakan analisis sidik ragam pada tingkat kepercayaan $95 \%$, bila ada perbedaan perlakuan di lanjutkan dengan uji Tukey untuk melihat perbedaan pengaruh antar perlakuan tersebut.

\section{HASIL}

\section{Total Suspended Solid (TSS)}

Gambar 1 memperlihatkan bahwa semakin meningkat kepadatan kijing Taiwan maka nilai TSS semakin rendah. Perlakuan D yang merupakan perlakuan kepadatan kijing taiwan tertinggi (5 ind/wadah) memiliki nilai 
TSS yang terendah $(0.45 \mathrm{mg} / \mathrm{l})$, kemudian diikuti secara berurutan oleh perlakuan $\mathrm{C}$ (4 ind/wadah), B (3 ind/wadah), dan perlakuan A (tanpa kijing taiwan) yaitu $0,58 \mathrm{mg} / 1,0,88 \mathrm{mg} / 1$ dan $0,90 \mathrm{mg} / \mathrm{l}$. Hasil analisis ragam (Anova) menujukkan bahwa keempat perlakuan yang dicobakan tidak berbeda nyata.

Akumulasi nilai TSS pada setiap pengukuran (waktu per 10 hari) selama penelitian juga memperlihatkan grafik nilai yang berbeda-beda (Gambar 2). Secara umum, grafik tersebut memperlihatkan trend akumulasi TSS yang semakin meningkat dengan bertambahnya waktu pemeliharaan organisme pada semua perlakuan. Walaupun hasil Anova menujukkan tidak ada perbedaan nyata antara perlakuan, namun setiap perlakuan dengan adanya kijing taiwan (A. woodiana) grafik akumulasi TSS semakin datar dengan bertambahnya kepadatan kijing Taiwan ( $A$. woodiana) dalam perlakuan.

\section{Total Organik Matter (TOM)}

Gambar 3 memperlihatkan semakin meningkatnya perlakuan kepadatan kijing ( $A$. woodiana) maka nilai TOM semakin rendah. Perlakuan D yang merupakan perlakuan kepadatan kijing taiwan tertinggi (5 ind/wadah) memiliki nilai TOM yang terendah $(1.82 \mathrm{mg} / \mathrm{l})$, kemudian diikuti secara berurutan oleh perlakuan C (4 ind/wadah), B (3 ind/wadah), dan perlakuan A (tanpa kijing taiwan) yaitu $1,88 \mathrm{mg} / \mathrm{l}, 2,25 \mathrm{mg} / \mathrm{l}$ dan 4,31 mg/l. Hasil analisis ragam (Anova) menujukkan bahwa keempat perlakuan yang dicobakan terdapat perbedaan secara nyata. Hasil analisis lanjut Tukey diperoleh informasi bahwa Perlakuan D, $\mathrm{C}$, dan Perlakuan B ketiganya tidak berbeda, namun berbeda nyata dengan perlakuan A.
Akumulasi nilai TOM pada setiap pengukuran (waktu per 10 hari) selama penelitian tertera pada Gambar 4. Gambar tersebut memperlihatkan trend grafik akumulasi TOM semakin meningkat dengan bertambahnya waktu pemeliharaan organisme ikan nila pada semua perlakuan. Hanya saja meningkatnya kepadatan kijing taiwan (A. woodiana) sebagai perlakuan dalam media pemeliharaan ikan nila (O. Niloticus), grafik akumulasi TOM yang terukur lebih rendah dan lebih datar selama masa pemeliharaan.

\section{Pertumbuhan Mutlak}

Gambar 5 memperlihatkan pertumbuhan mutlak rata-rata ikan nila yang dipelihara dengan sistem biofilter adalah 18,53 $\pm 1,07 \mathrm{~g}$, $19,72 \pm 0,38 \mathrm{~g}, 20,62 \pm 0,90 \mathrm{~g}$, dan $21,45 \pm 1,65 \mathrm{~g}$ untuk perlakuan A, B, C, dan D secara berturutturut. Hasil analisis ragam menunjukkan bahwa perlakuan kepadatan kijing Taiwan ( $A$. woodiana) sebagai biofilter dalam pemeliharaan memberikan pengaruh yang signifikan $(\mathrm{P}<0,05)$ terhadap pertumbuhan ikan nila $(O$. niloticus $)$. Hasil uji lanjut Tukey diperoleh informasi bahwa perlakuan $\mathrm{D}$ tidak berbeda nyata dengan perlakuan $\mathrm{C}$ dan perlakuan $\mathrm{D}$ tetapi berbeda nyata dengan perlakuan A. Selanjutnya Perlakuan C, B, dan Perlakuan A ketiganya tidak berbeda nyata.

\section{Tingkat Kelangsungan Hidup}

Rata-rata tingkat kelangsungan hidup organisme pemeliharaan ikan nila (A. niloticus) di akhir penelitian nilai yang sama. Tingkat kelangsungan hidup ikan nila peliharaan pada keempat perlakuan yaitu memberikan hasil yang sama yaitu $100 \%$.

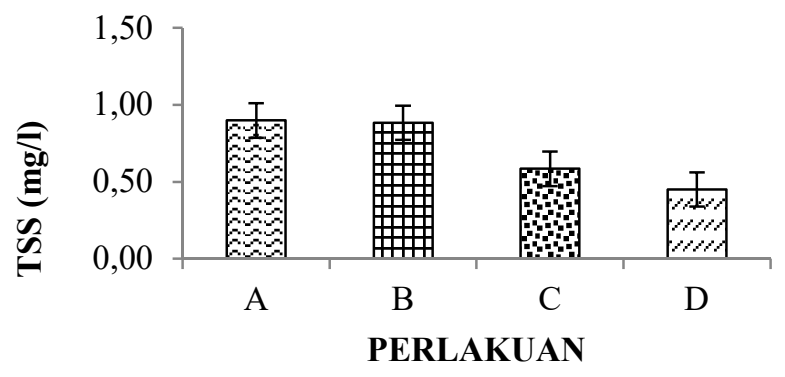

Gambar 1. Nilai total suspended solid (TSS) masing-masing perlakuan kepadatan kijing Taiwan (A.woodiana) pada pemeliharaan ikan nila. $(\mathrm{A}=$ kontrol, $\mathrm{B}=3$ kijing taiwan, $\mathrm{C}=4$ kijing taiwan dan $\mathrm{D}=5 \mathrm{kijing}$ taiwan). 


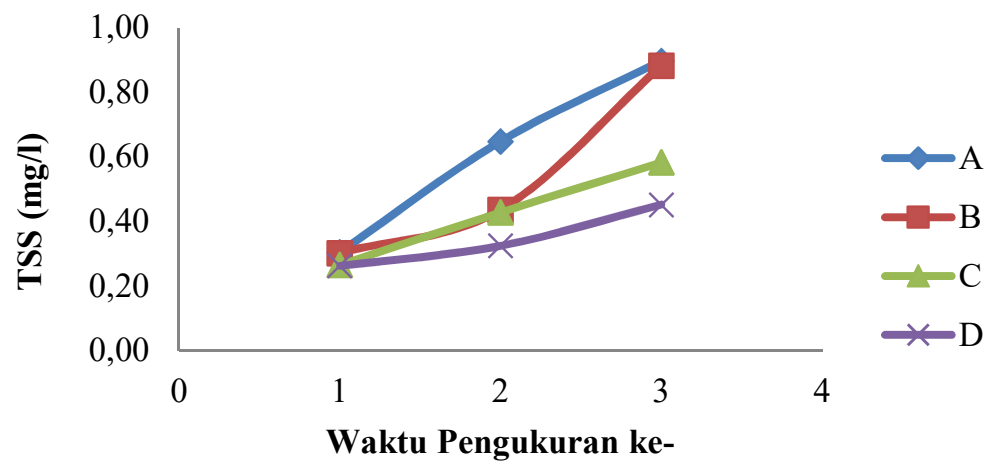

Gambar 2. Grafik akumulasi total suspended solid (TSS) masing-masing perıakuan kepadatan kijing taiwan (A.woodiana) yang diukur per 10 hari selama pemeliharaan ikan nila. $(\mathrm{A}=$ kontrol, $\mathrm{B}=3 \mathrm{kijing}$ taiwan, $\mathrm{C}=4$ kijing taiwan dan $\mathrm{D}=5$ kijing taiwan)

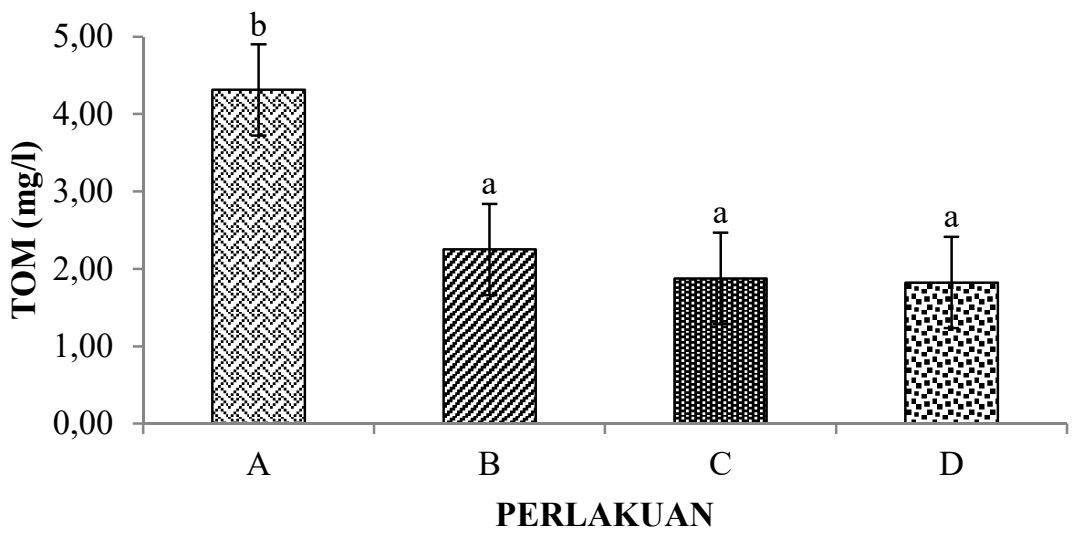

Gambar 3. Nilai TOM masing-masing perlakuan kepadatan dalam pemeliharaan ikan nila (O.niloticus) pada ikan nila. ( $\mathrm{A}=$ kontrol, $\mathrm{B}=3$ kijing taiwan, $\mathrm{C}=4$ kijing taiwan dan $\mathrm{D}=5$ kijing taiwan). ${ }^{\mathrm{a}, \mathrm{b}}$ superscript yang berbeda menunjukkan perbedaan signifikan pada taraf $\alpha=0,05$.

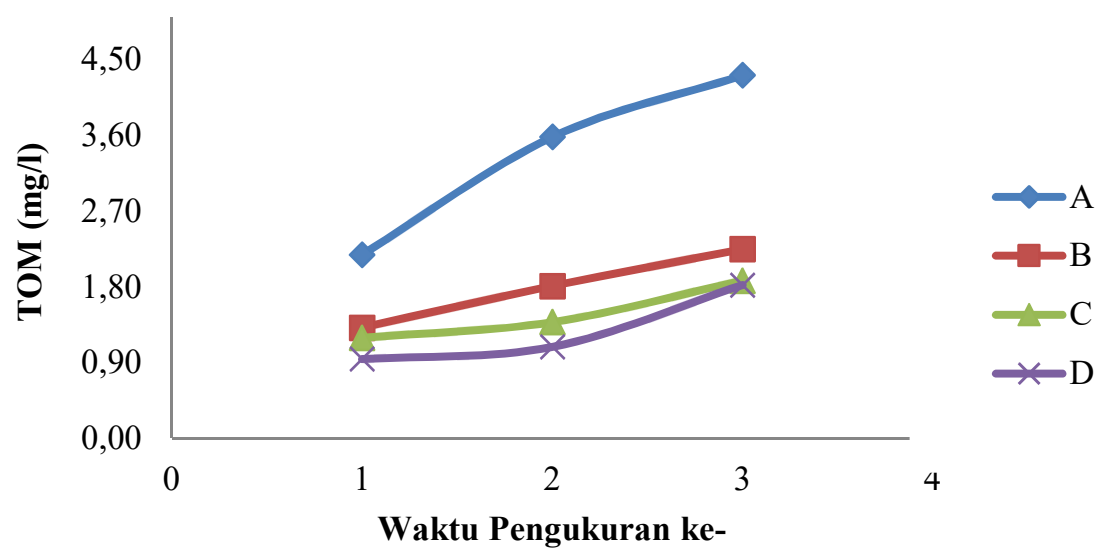

Gambar 4. Grafik akumulasi total organik matter (TOM) pada masing- masing perlakuan kepadatan kijing Taiwan (A. woodiana) yang diukur per 10 hari selama pemeliharaan ikan nila. $(\mathrm{A}=$ kontrol, $\mathrm{B}=3$ kijing taiwan, $\mathrm{C}=4$ kijing taiwan dan $\mathrm{D}=5$ kijing taiwan). 


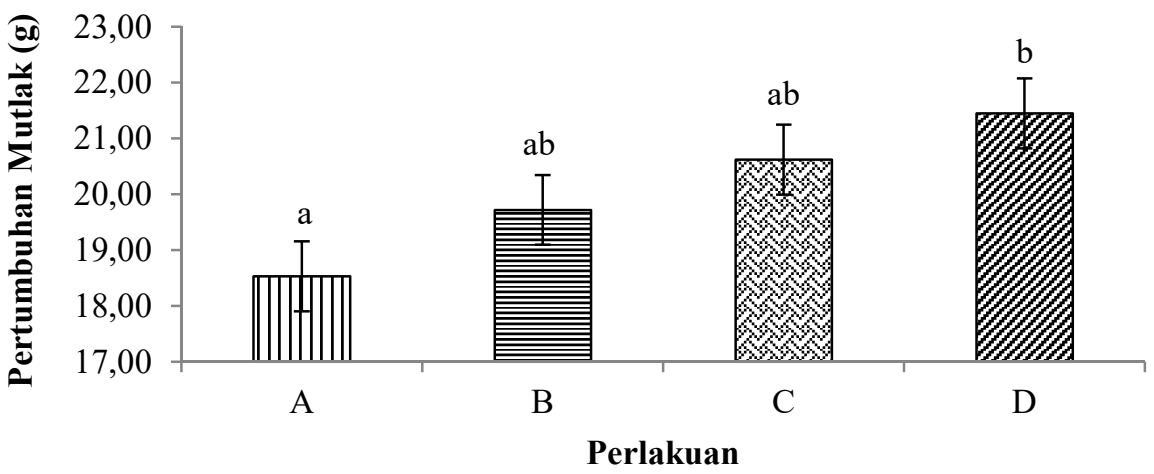

Gambar 5. Rata-rata Pertumbuhan Mutlak organisme pemeliharaan ikan (O.niloticus) pada masing-masing perlakuan kepadatan kijingTaiwan (A.woodiana) sebagai biofilter ( $\mathrm{A}=$ kontrol, $\mathrm{B}=3$ kijing taiwan, $\mathrm{C}=4$ kijing taiwan dan $\mathrm{D}=5$ kijing taiwan). ${ }^{\mathrm{a}, \mathrm{b}}$ superscript yang berbeda menunjukkan perbedaan signifikan pada taraf $\alpha=0,05$.

\section{PEMBAHASAN}

Padatan tersuspensi total (Total suspended solid) adalah bahan tersuspensi yang tertahan pada saringan millipore pada ukuran pori-pori $0,45 \mu \mathrm{m}$. TSS terdiri dari bahan organik dan anorganik. Sifat fisik suspensi, seperti titik beku atau tekanan uap suspensi padatan dalam cairan, kurang dipengaruhi oleh partikel yang tersuspensi (Fatimah $d k k, 2014$ ).

Hasil Gambar 1 terlihat bahwa semakin kearah kanan dari perlakuan penelitian nilai TSS semakin rendah Hasil analisis ragam (Anova) menujukkan bahwa keempat perlakuan yang dicobakan tidak berbeda nyata. Hal ini mengindikasikan bahwa dengan kepadatan kijing Taiwan (A.woodiana) sebagai biofilter dalam media pemeliharaan organisme budidaya maka nilai TSS media semakin menurun. Hasil TSS pada akuarium perlakuan A (tanpa biofilter) lebih tinggi nilainya di banding akuarium lainnya yang ada kijing taiwan (perlakuan 3 ind, 4 ind, dan perlakuan 5 ind per wadah). Purba (2009) juga menyatakan bahwa penurunan kadar TSS lebih tinggi pada perlakuan dengan adanya kerang sebagai biofilter dibanding dengan tanpa adanya organisme biofilter. Sisa pakan dan sisa metebolisme ikan peliharaan yang tertampung di dalam media mengakibatkan penurunan kualitas air, terlebih bila terjadi proses penumpukan bahan-bahan organik di dasar akuarium pemeliharaan dalam waktu relatif lama. Tullah (2018) menyatakan bahwa padatan tersuspensi total (Total Suspended Solid/TSS) adalah bahan tersuspensi dan tidak larut dalam air. Padatan ini dapat mempengaruhi nilai parameter fisik media lainnya seperti kekeruhan dan kecerahan air. Palinussa (2010) juga menyatakan bahwa padatan tersuspensi dalam air terdiri dari plankton, sisa metabolisme mahluk hidup, lumpur dan limbah lainnya. Hal ini sejalan dengan Putra $d k k$, (2016) bahwa Kijing taiwan (A. woodiana) merupakan organisme filter feeder yaitu pemakan dengan cara menyaring zooplankton, fitoplankton dan detritus. Hal ini diperkuat berdasarkan analisis isi lambung kijing taiwan terdiri dari plankton, bakteri, alga hijau bersel satu, flagellate, diatom, protozoa dan dedritus (Tullah, 2018).

Akumulasi nilai TSS pada setiap pengukuran (waktu per 10 hari) selama penelitian tertera pada Gambar 2 yang memperlihatkan trend akumulasi TSS yang semakin meningkat dengan bertambahnya waktu pemeliharaan organisme pada semua perlakuan. Walaupun hasil Anova menujukkan tidak ada perbedaan nyata antar perlakuan, namun dengan meningkatnya kepadatan kerang kijing Taiwan (A. woodiana) dalam wadah perlakuan, grafik akumulasi TSS semakin rendah dan cenderung semakin datar. Hal ini mengindikasikan bahwa semakin tinggi kepadatan kijing Taiwan (A. woodiana) yang dicobakan maka akumulasi sisa pakan dan hasil metabolisme organisme ikan peliharaan dalam media semakin rendah pula, demikian sebaliknya. Akumulasi TSS dalam media pemeliharaan ikan nila (O. niloticus) yang lebih rendah akan cenderung lebih lama bertahan kualitas media pemeliharaan ikannya. Peningkatan akumulasi TSS pada perlakuan D, 
C dan perlakuan B pada setiap waktu pengukuran jauh lebih rendah yang hanya berkisar $0.19 \mathrm{mg} / 1$ dibanding dengan perlakuan tanpa adanya kijing taiwan yang pertambahan akumulasinya mencapai sekitar $0.59 \mathrm{mg} / 1$. Nilai yang diperoleh pada penelitian dapat menggambarkan bahwa peningkatan kadar TSS yang rendah pada perlakuan D, C, dan Perlakuan B disebabkan oleh adanya organisme biofilter kijing taiwan yang memanfaatkan sisa pakan, feses dan buangan hasil metabolisme ikan secara berkesinambungan sebagai sumber makanan selama percobaan pemeliharaan berlangsung. Hal ini sejalan dengan Nugroho (2006) bahwa penerapan sistem biofilter dengan menggunakan organisme hidup seperti kerang air tawar dapat mengurangi konsentrasi bahan organik yang tersuspensi, dapat menekan limbah $\mathrm{N}$ dan $\mathrm{P}$, menjaga kualitas air tetap stabil dan buangan limbah akan berkurang ke badan air di sekitarnya Di sisi lain, keberadaan TSS dengan konsentrasi tinggi dalam media dapat mempengaruhi parameter fisik lingkungan media lainnya seperti kekeruhan. Supriyantini $d k k$. (2017) melaporkan bahwa TSS media memiliki hubungan yang semu (korelasi positif) dengan parameter kekeruhan, semakin tinggi nilai TSS maka kekeruhan juga akan semakin tinggi sementara dengan parameter kecerahan memiliki hubungan terbalik dimana semakin rendah nilai TSS maka kecerahan akan semakin tinggi.

Bahan organik yang dimanfaatkan oleh kijing taiwan yaitu dari sisa pakan dan feses yang mengendap didasar wadah pemeliharaan. Kijing Taiwan mengkonsumsi sumber energi dari sisa pakan yang mengandung protein dan lemak, dimana pakan yang digunakan dalam pemeliharaan ikan nila memiliki komposisi nutrisi yaitu protein kasar 35\%, lemak kasar $2 \%$, serat kasar 3\%, abu kasar 13\% dan kadar air $12 \%$ yang merupakan produksi PT. Sentral Proteina Prima, tbk. Sisa metabolisme dan sisa pakan yang tersuspensi dapat menyebabkan medium pemeliharaan menjadi keruh. Semakin keruhnya suatu perairan dapat mengurangi cahaya matahari untuk masuk kedalam perairan dan dapat menghambat fitoplankton dan tanaman air lainnya untuk berfotosintesis. Jika hal ini terjadi dapat menurunkan produktifitas perairan dan terjadi penurunan kualitas air. Meningkatnya sisa pakan dan buangan metabolit yang terakumulasi dapat menyebabkan kualitas air menjadi rendah yaitu menurunnya kadar oksigen terlarut pada perairan(Afriansyah dkk., 2016). Kosentrasi fosfat yang tinggi akan mengganggu proses metabolisme bahkan dapat mengakibatkan kematian pada ikan (Ebeling et al., 2006). Olehnya dalam Baku mutu air untuk keperluan budidaya air tawar berdasarkan peraturan pemerintah No. 82 tahun 2001, batas ambang dari TSS dalam air yaitu $50 \mathrm{mg} / 1$ yang diukur dengan metode gravimetri. Hasil penelitian yang diperoleh menunjukkan kosentrasi TSS media peliharaan jauh di bawah dari batas yang disyaratkan tersebut, pemanfaatan organisme biofilter dalam media sangat menunjang aktivitas budidaya yang berkelanjutan.

TOM (Total Organic Matter) merupakan suatu gambaran kandungan bahan organik total pada suatu perairanyang terdiri dari bahan organik terlarut, tersuspensi (particulate) dan koloid (Nugroho et al. 2014). Bahan organik di suatu perairan lebih banyak dalam bentuk terlarut dibandingkan dalam tersuspensi atau koloid (Hadinafta, 2009). Hasil pengukuran TOM pada Gambar 3dapat dilihat bahwa semakin kearah kanan dari perlakuan nilai TOM semakinrendah. Hasil akumulasi TOM masing-masing perlakuan selama penelitian (Gambar 4) juga memperlihatkan bahwa perlakuan kepadatan kijing taiwan (A.woodiana) yang lebih tinggi dalam wadah pemeliharaan organisme uji menghasilkan grafik TOM yang lebih rendah dengan trend yang lebih stabil selama masa pemeliharaan tersebut. Peningkatan akumulasi TOM pada perlakuan D, C,danperlakuan B pada setiap waktu pengukuran jauh lebih rendah $(0,87$ $\mathrm{mg} / \mathrm{l})$ dibanding dengan perlakuan tanpa kijing taiwan yang pertambahan akumulasinya dapat mencapai hampir tiga kali lipat yaitu $2.13 \mathrm{mg} / 1$. Dari nilai yang diperoleh pada penelitian dapat menggambarkan bahwa penurunan kadar TOM, selama percobaan disebabkan oleh adanya penguraian mikroba dan partikel bahan tersuspensi dimanfaatkan olehkijing Taiwan. Hal ini sesuai dengan pernyataan Tullah (2018) bahwa Kijing taiwan (A. woodiana) merupakan organisme filter feeder yaitu pemakan dengan cara menyaring bahan organic, zooplankton, fitoplankton dan detritus, bersifat statis menerima makanan melalui air yang masuk ke dalam tubuhnya. Kehidupan kijing yang tergantung dari makanan alami yang tersedia di 
perairan serta kecepatan air yang masuk melalui sifonnya.

Bahan organik yang dimanfaatkan oleh kijing taiwan yaitu dari sisa pakan dan feses yang mengendap didasar wadah pemeliharaan. Amoniak dalam sistem budidaya diawali nitrogen yang berasal dari pakan yang diberikan pada ikan, pakan yang tidak dikonsumsi, feses dan hasil metabolisme, Afriansyah $d k k$, (2016). Dalam kegiatan budidaya perikanan, masukan bahanorganik berasal dari sisa-sisa pakan yang tidak termakan dan mengendap di dasar perairan, kadar bahan organik total perairan yang ideal untuk budidaya berkisar antara 20$30 \mathrm{mg}^{-1} \mathrm{l}^{-1}$. Dalam penelitian yang dilakukan kosentrasi TOM yang diperoleh masih jauh di bawah batas toleransi dan jauh dari ambang batas yang dapat mempengaruhi kelangsungan hidup organisme uji.

Laju pertambahan nilai TOM yang terendah hari ke-10 didapatkan pada perlakuan D (5 ind/wadah) sebesar $0,95 \mathrm{mg} / 1$ (hari ke10), $1,09 \mathrm{mg} / 1$ (hari ke-20) dan sebesar 1,82 $\mathrm{mg} / \mathrm{l}$ pada hari ke-30. Laju pertambahan nilai TOM perlakuan C (4 ind per wadah) pada setiap pengukuran mengalami peningkatan masing-masing sebesar $1,20 \mathrm{mg} / 1,1,38 \mathrm{mg} / 1$, dan $1,88 \mathrm{mg} / 1$, sedangkan perlakuan B (3 ind per wadah) setiap pengukuran juga mengalami peningkatan masing-masing sebesar $1,32 \mathrm{mg} / 1$, $1,81 \mathrm{mg} / \mathrm{l}$, dan 2,25 mg/l. Selanjutnya pengukuran nilai TOM pada perlakuan A (tanpa biofilter) mengalami peningkatan drastis selama waktu pengukuran per sepuluh hari pemeliharaan yaitu masing-masing sebesar 2,18 $\mathrm{mg} / 1,3,58 \mathrm{mg} / 1$, dan $4,31 \mathrm{mg} / 1$. Bertambahnya waktu pemeliharaan ikan nila seperti pengukuran TOM pada hari ke-20 dan hari ke30 mengakibatkan meningkatnya sisa pakan yang tidak dimakan dan sisa metabolisme dari kedua organisme tersebut yang terakumulasi dalam wadah pemeliharaan. Dilakukannya pemberian pakan dua kali sehari (pagi dan sore) secara adlibitum sehingga nilai TOM meningkat sejalan bertambahnya waktu pemeliharaan. Akumulasi nilai TOM yang tinggi pada setiap rentang waktu pengukuran dapat mengakibatkan kekeruhan pada media budidaya. Prayoga $d k k$., (2012) menyatakan bahwa amoniak yang dihasilkan dari sisa pakan dan metabolisme ikan dapat mengakibatkan penumpukan bahan organik yang menyebabkan terjadinya penurunan kualitas air. Menurut
Tullah (2018) pemanfaatan kijing Taiwan merupakan salah satu cara untuk mengurangi bahan organik dari sisa aktivitas budidaya ikan air tawar. Kijing taiwan dapat memanfaatkan sisa pakan dan hasil metabolisme ikan.

Walaupun setiap perlakuan nilai TOM mengalami peningkatan selama pemeliharaan tetapi pada hasil yang diperoleh bahwa semakin meningkat kepadatan kijing Taiwan nilai TOM semakin rendah. Hasil nilai TOM pada Gambar 4 tersebut membuktikan bahwakijing Taiwan berfungsi sebagai biofilter dengan memanfaatkan sisa pakan dan feses dalam wadah pemeliharaan. Semakin tinggi kepadatan kijing Taiwan maka nilai TOM dapat menurun dua kali lipat di banding perlakuan A tanpa adanya kijing Taiwan. Menurut Putra (2016) Kijing mampu menekan cemaran yang terdapat pada air, parameter yang mampu di pulihkan antara lain kandungan bahan organik dimana hewan filter feeder mampu menyaring partikel yang ada di air.

Perubahan suhu pada media pemeliharaan ikan nila dengan biofioter kijing Taiwan (A. woodiana) dalam skala laboratorium tidak memberikan pengaruh yang signifikan terhadap perubahan suhu air. Suhu rata-rata media pada awal penelitian dan akhir penelitian yaitu $27{ }^{\circ} \mathrm{C}$ hal ini sesuai dengan pernyataan Zainura $d k k$ (2016) bahwa faktor utama yang bisa menaikkan suhu air secara alami di perairan adalah tingginya penyinaran matahari sepanjang hari di tepian atau daerah budidaya. Selanjutnya Gusrina (2008) mengemukakan bahwa suhu di perairan dapat dipengaruhi oleh beberapa faktor seperti musim, penyinaran matahari dan waktu. Pada penelitian ini, perubahan suhu tidak terlalu mencolok karena media penelitian terletak didalam ruangan laboratorium. Perubahan suhu dapat diakibatkan oleh proses metabolisme dan perombakan sisa feses ikan yang ada dalam media budidaya.

Relatif lebih baiknya parameter fisik media khususnya TSS dan TOM dengan meningkatnya kepadatan kijing taiwan ( $A$. woodiana) dalam media pemeliharaan, kelihatannya berdampak baik pula bagi pertumbuhan mutlak ikan nila (O. niloticus). Kepadatan kijing taiwan (A. woodiana) dalam media pemeliharaan seperti pada perlakuan D (5 ind/wadah) dan perlakuan C (4 ind/wadah) lebih baik pertumbuhan mutlak ikan nila $(O$. 
niloticus) peliharaan dibandingkan perlakuan $\mathrm{B}$ (3 ind/wadah) dan perlakuan A (kontrol). Hal ini sejalan dengan Putra $d k k$ (2016) adanya kijing taiwan (A. woodiana) dalam media pemeliharaan ikan menyebabkan terjadinya proses filterisasi yang mampu menghasilkan kualitas air pemeliharaan ikan yang lebih baik. Hasil penelitian diperoleh juga sejalan dengan Safaringga $\quad d k k \quad$ (2017) yang menyatakanbahwapertumbuhanikan di pengaruhi oleh faktor internal dan factor eksternal. Faktor internal sebagianbesartergantung pada kondisi tubuh ikan, misalnya kemampuan ikan dalam memanfaatkan sisa energi dan protein setelah metabolisme, sedangkan faktor eksternal menyangkut kondisi lingkungan, dan kualitas air yang baik. Olehnya fungsi pemanfaatan bahan organik oleh kijing Taiwan sangat berpengaruh terhadap pertumbuhan ikan nila yang di pelihara. Hal ini juga sejalan dengan pernyataan Palinussa (2010) bahwa Kelangsungan hidup merupakan persentase organisme yang hidup pada akhir pemeliharaan dari jumlah organisme awal yang di pelihara dalam suatu wadah.

Pertumbuhan terendah terdapat pada perlakuan $\mathrm{A}$, ini diduga kualitas air yang buruk dikarenakan tanpa adanya biofilter dalam media pemeliharaan. Amonia dapat meningkat dalam media disebabkan oleh limbah dari sisa pakan dan feses yang dapat memperburuk kualitas air. Pengaruh dari amonia yang tinggi pada ikan ialah nafsu makan kurang dan mudah terserang penyakit. Hal ini sesuai dengan Putra $d k k$ (2016) yang menyatakan amonia dalam air mempengaruhi nafsu makan, metabolisme serta mudah terserang penyakit karena dapat mereduksi masukan oksigen yang disebabkan oleh rusaknya insang.

Tingkat kelangsungan hidup ikan nila sebagaimana data perolehan bahwa semua perlakuan penelitian kepadatan kijing taiwan dalam wadah pemeliharaan ikan nila memberikan hasil yang sama yaitu $100 \%$. Organisme pemeliharaan ikan nila (O. niliticus) hidup hingga akhir penelitian relatif masih terjaganya kualitas dan kuantitasairnya. Demikian, pemberian pakan selama pemeliharaan sebagai aktivitas hidup ikan nila semua dapat pula terjaga dengan baik. Hal ini diduga bahwa selama penelitian ikan nila dan kijingtaiwan dapat hidup dalam media yang sama serta tidak terjadi persaingan dalam pemanfaatan ruang dan makanan. Hal ini juga sejalan dengan pernyataan Palinussa (2010) bahwa Kelangsungan hidup merupakan persentase organisme yang hidup pada akhir pemeliharaan dari jumlah organisme awal yang di pelihara dalam suatu wadah.

\section{KESIMPULAN}

Penggunaan kerang kijing taiwan ( $A$. woodiana) sebagai biofilter lebih dapat mempertahankan kuantitas konsentrasi total suspended solid (TSS) dan parameter total organic matter (TOM) pada media pemeliharaan ikan nila (O. niloticus). Semakin tinggi kepadatan kerang kijing taiwan ( $A$. woodiana) yang digunakan, maka nilai parameter TSS dan TOM dalam media pemeliharaan relatif rendah dan lebih stagnan (stabil) selama masa pemeliharaan ikan nila $(O$. niloticus). Tingkat kepadatan kerang kijing taiwan (A. woodiana) yang lebih tinggi dalam media (5 ind/wadah) juga memberikan pengaruh signifikan terhadap pertumbuhan mutlak ikan nila, tetapi tidak berpengaruh signifikan terhadap kelulushidupan ikan nila.

\section{REFERENSI}

Afriansyah, A., Dewiyanti, I., \& Hasri, I. (2016). Keragaan Nitrogen dan T-Phosfat pada Pemanfaatan Limbah Budidaya Ikan Lele (Clarias gariepinus) oleh Ikan Peres (Osteochilus kappeni) dengan Sistem Resirkulasi. Jurnal Ilmiah Mahasiswa Kelautan dan Perikanan Unsyiah. 1(2): 252-261.

Ebeling, J. M., Welsh, C. F., \& Rishel, K. L. (2006). Performance evaluation of an inclined belt filter using coagulation/flocculation aids for the removal of suspended solids and phosphorus from microscreen backwash effluent. Aquacultural Engineering. 35(1): 61-77. https://doi.org/10.1016/j.aquaeng.2005.0 8.006

Fatimah A, Harmadi \& Wildian. (2014). Perancangan Alat Ukur TSS (Total Suspended Solid) Air Menggunakan Sensor Serat Optik Secara Real Time. Jurnal Ilmu Fisika Universitas Andalas, 6(2), $\quad$ 68-73. 
Media Akuatika : Jurnal Ilmiah Jurusan Budidaya Perairan. 2021. 6(4): 174-183.

https://doi.org/10.25077/jif.6.2.6873.2014

Gusrina. 2008. Budidaya Ikan. Direktorat pembinaan sekolah menengah kejuruan. Jakarta.

Hadinafta R. 2009. Analisis Kebutuhan Oksigen Untuk Dekomposisi Bahan Organik Di Lapisan Dasar Perairan Estuari Sungai Cisadane, Tangerang. Skripsi. Institut Pertanian Bogor. Bogor.

Indriyastuti, J. F., Muskananfola, M. R., \& Widyorini, N. (2014). Analisis total bakteri, tom, nitrat dan fosfat di Perairan Rowo Jombor, Kabupaten Klaten. Management of Aquatic Resources Journal (MAQUARES). 3(4): 102-108. DOI: https://doi.org/10.14710/marj.v3i4.7037

Nugroho, A. E. 2006. Tingkat Biofiltrasi Kijing (Pilsbryoconcha Exilis) Terhadap Bahan Organik. Skripsi. Departemen Manajemen Sumberdaya Perairan, Fakultas Perikanan dan Ilmu Kelautan, Institut Pertanian Bogor. Bogor

Palinussa, M. E. 2010. Pemanfaatan Kijing Taiwan (A. woodiana, Lea) sebagai Biofilter pada Sistem Budidaya Ikan Mas.Tesis. Sekolah Pasca Sarjana Institut Pertanian Bogor.

Peraturan Pemerintah Repoblik Indonesia, 2001.Undang- undang Nomor 82 Tahun 2001 tentang Persyaratan Kualitas Air Minum dan Pengendalian Pencemaran Air. Jakarta.

Sari, I. P., Yulisman, Muslim. (2017). Laju pertumbuhan dan efisiensi pakan ikan nila (Oreochromis niloticus) yang dipelihara dalam kolam terpal yang dipuasakan secara periodik. Jurnal Akuakultur Rawa Indonesia, 5(1), 45-55.

Purba, K. (2009). Analisa Kadar Total Suspended Solid (TSS), Amoniak (NH3), Sianida (CN-) dan Sulfida (S2-) Pada Limbah Cair Bapedaldasu. Departemen Kimia, Program Studi Diploma-3 Kimia Analis, Fakultas MIPA Sumatera Utara. Medan.

Putra, S., Arianto, A., Efendi, E., Hasani, Q., \& Yulianto, H. (2016). Efektifitas Kijing Air Tawar (Pilsbryoconcha exilis) Sebagai Biofilter Dalam Sistem Resirkulasi Terhadap Laju Penyerapan Amoniak Dan Pertumbuhan Ikan Lele
Sangkuriang (Clarias Gariepinus). eJurnal Rekayasa dan Teknologi Budidaya Perairan, 4(2): 497-506.

Safaringga, R., El Rahimi, S. A., \& Mellisa, S. (2017). Pemanfaatan Kerang Air Tawar (Anodonta woodiana) Sebagai Biofilter Terhadap Pertumbuhan Benih Ikan Nila (Oreochromis Niloticus). Jurnal Ilmiah Mahasiswa Kelautan Perikanan Unsyiah, 2(3): 429-437.

Supriyantini, E., Nuraini, R. A. T., \& Fadmawati, A. P. (2017). Studi kandungan bahan organik pada beberapa muara sungai di kawasan ekosistem mangrove, di wilayah pesisir pantai Utara Kota Semarang, Jawa Tengah. Buletin Oseanografi Marina, 6(1): 29-38. DOI:

https://doi.org/10.14710/buloma.v6i1.15 739

Tullah, A. H. (2018). Efektivitas Kijing Taiwan (Anodonta woodiana) Dalam Menurunkan Bahan Organik Dari Sisa Aktivitas Budidaya Ikan Air Tawar Dengan Perbedaan Kerapatan. Disertisasi. Universitas Brawijaya. Malang.

Vrahmana, A., Basuki, F., \& Rejeki, S. (2013). Hibridisasi Ikan Nila Pandu dan Kunti Generasi f4 Terhadap Efek Heterosis pada Ikan Nila Larasati (Oreochromis niloticus) Generasi F4 Pada Umur 5 Bulan. Journal of Aquaculture Management and Technology, 2(4): 3139.

Zainura, Z., Rusydi, R., \& Khalil, M. (2016). Studi pembesaran tiram (Crassostrea sp) melalui desain tata letak yang berbeda. Acta Aquatica: Aquatic Sciences Journal, 3(2), 54-61. DOI: https://doi.org/10.29103/aa.v3i2.393 